\title{
DA CORRESPONDÊNCIA À INTERNET: O ENSINO DE INGLÊS A DISTÂNCIA NO BRASIL
}

\author{
CARLOS FABIANO DE SOUZA ${ }^{1}$
}

Departamento de Ensino e Aprendizagem, Instituto Federal Fluminense Estrada Cabo-Frio-Búzios, s/no - 28909-971 - Baía Formosa - Cabo Frio - RJ - Brasil

\begin{abstract}
Resumo. Este artigo busca apresentar um olhar sobre o percurso histórico do ensino e da aprendizagem de inglês a distância no Brasil, com o intuito de dar a ver os sentidos postos em circulação sobre aprender inglês em diferentes contextos de EAD. Para empreender as análises, priorizamos uma gama de textos, materializados sob a forma de folhetos impressos e panfletos de divulgação digital, recuperados por meio da Internet. Como suporte teórico, lança-se mão da Análise de discurso (AD) de base enunciativa, fundamentando-se, particularmente, em concepções advindas da semântica global (MAINGUENEAU, 2008), pela qual o funcionamento discursivo é tomado em suas múltiplas dimensões.
\end{abstract}

Palavras-chave: ensino por correspondência; inglês a distância; análise de discurso; semântica global.

\begin{abstract}
This paper aims at presenting a view about the historic itinerary of the teaching and learning of English at distance in Brazil, with the purpose of showing the meanings in circulation about learning English within different DE contexts. To proceed with the analyses, we have prioritized an amount of texts recovered through the Internet. As a theoretical framework, our study is grounded in the Discourse analysis (DA) of enunciative basis, supported, particularly, by the conceptions from the global semantics (MAINGUENEAU, 2008), by which the discursive functioning is considered in its multiple dimensions.
\end{abstract}

Keywords: teaching by correspondence; distance English course; discourse analysis; global semantics.

\section{Considerações iniciais}

Não se pode negar que a relação do ser humano com a tecnologia é constitutiva do próprio processo de evolução pelo qual passa a humanidade. Em seu percurso de vida, o homem se constrói em contato com a natureza, transformando-a e a si mesmo, por meio de um processo de aprendizagem contínuo e dinâmico, empregando todo o seu potencial

\footnotetext{
${ }^{1}$ Doutorando em Estudos de Linguagem pela Universidade Federal Fluminense. Docente de inglês na Carreira de Magistério do Ensino Básico, Técnico e Tecnológico (EBTT) do Instituto Federal Fluminense campus Cabo Frio-RJ.
} 
inventivo e técnico no desenvolvimento de novas formas de modificar socialmente o mundo no qual ele vive. É nesse sentido que se pode dizer que "as tecnologias são tão antigas quanto a espécie humana" (KENSKI, 2007, p. 15).

Historicamente, a presença da tecnologia em contextos educacionais sempre esteve presente, tal que os avanços tecnológicos, ao longo dos tempos, têm contribuído com novos caminhos de se pensar o fazer pedagógico, ampliando o acesso ao conhecimento, por meio de recursos educacionais cuja adoção se propõe a melhorar a qualidade das práticas de ensino e aprendizagem.

Nesse aspecto, entende-se que os diferentes aparatos tecnológicos a serviço do homem tendem a influenciar diretamente na definição de teorias, na concepção de métodos e propostas de integração da tecnologia às práticas de ensino, com o intuito de trazer benefícios à aprendizagem dos estudantes, impactando, assim, na melhoria da educação como um todo.

Ainda que nos dias de hoje o termo tecnologia se confunda por vezes ao uso da internet, ou mesmo ao uso de aparelhos eletrônicos digitais, cada vez mais modernos, não se pode perder de vista que a tecnologia pode ser algo simples, desde uma folha de papel à lousa interativa, cuja relevância está associada ao seu papel de ampliar o potencial humano, seja físico ou intelectual (KAMPFF, 2009). Como bem nos lembra esta estudiosa, "as tecnologias empregadas com fim educacional colaboram nesse sentido, ampliando as possibilidades do professor ensinar e do aluno aprender" (KAMPFF, 2009, p. 14).

Destaca-se, aqui, o papel desempenhado pelos materiais (instrumentos) e suportes (meios) utilizados na ancoragem dos processos de ensino e aprendizagem a distância, auxiliando significativamente na construção de conhecimento por parte dos estudantes. Acredita-se, pois, que diferentes contextos, em distintas épocas, ensejam modos particulares de se fazer uso da tecnologia no que tange ao desenvolvimento de práticas de ensino e aprendizagem, visto que a sociedade vai mudando constantemente em suas formas de organização, de produção de bens, de comercialização de dispositivos tecnológicos, de ensinar e aprender (MORAN, 2000).

No que se refere ao ensino e à aprendizagem de inglês, por exemplo, é correto afirmar que, a depender do material didático utilizado para se aprender uma língua estrangeira (LE), a maneira como a linguagem é trabalhada tende a imbricar-se, de certa forma, com o tipo de suporte mobilizado para colocar em prática sua finalidade pedagógica, levando em conta, sobretudo, as demandas impostas pela sociedade quanto ao que se pretende com a construção de conhecimento significativo em um determinado idioma, neste caso especificamente, a língua da comunidade global: o inglês.

Nessa perspectiva, cabe destacar ainda o papel desempenhado pela educação a distância (EAD) ao longo de décadas no Brasil, em especial, em face de se levar em conta sobremaneira a formação que se pretende oferecer aos aprendizes, o que requer considerar as profundas transformações pelas quais tem passado a sociedade e os significados atribuídos ao processo de aprendizagem de uma LE, ressignificando-o com o passar dos tempos. 
Tendo em vista essas questões - e partindo de um recorte que se propõe a recuperar diferentes contextos de $\mathrm{EAD}$, desde o ensino de inglês por correspondência até experiências mais recentes de aprendizagem de LE por meio da Internet, este artigo busca apresentar um olhar sobre o percurso histórico do ensino e da aprendizagem de inglês a distância em nosso país, levando em conta os contextos de EAD e, de forma bastante resumida, suas condições específicas de produção.

Nosso objetivo com este texto é, então, dar a ver os sentidos postos em circulação sobre aprender inglês em diferentes contextos de EAD sem, no entanto, se configurar como uma possibilidade de esgotamento do tema. Em lugar, o que se propõe é a abertura para um campo de interlocução entre conceptualizações que aproximam linguagem e tecnologia sob a lente de um viés discursivo.

Nessa perspectiva, o material a ser analisado refere-se a enunciados postos em circulação em mídias impressa e/ou virtual, inscritos em folhetos impressos e panfletos de divulgação digital, recuperados por meio da Internet, e que se encontram atravessados por dizeres de ordem sócio-histórica, ideológica, que tendem a dar a ver os sentidos veiculados sobre aprender inglês em diferentes épocas, por meio de variados instrumentos e suportes.

Para empreender as análises, lança-se mão da Análise de discurso (AD) de base enunciativa, fundamentando-se, particularmente, em concepções advindas da semântica global (MAINGUENEAU, 2008), a qual toma o funcionamento discursivo em suas múltiplas dimensões, constituindo-se como uma rede de restrições.

A seguir, o texto se organiza em duas seções, quais sejam, "Educação a distância: uma história em curso", e "Funcionamento discursivo à luz de preceitos da semântica global". Em seguida, apresentamos as considerações finais, seguidas das referências.

\section{Educação a distância: uma história em curso}

Ao perscrutar a história da EAD pelo mundo, pode-se observar que, com o passar dos séculos, ela foi evoluindo, ampliando a sua atuação, sendo, inclusive, caracterizada em função dos recursos tecnológicos utilizados em seu tempo, tal que registros mais remotos de sua aplicação remontam ao século XVIII.

Conforme Peters (2012), qualquer trabalho de análise acerca do que se entende por EAD traz no bojo aspectos relevantes concernentes a experiências pedagógicas mais remotas, passando por diferentes perspectivas históricas e, por fim, culminando com empreitadas inovadoras pactuadas com a criação de universidades virtuais.

Ainda recorrendo às palavras desse estudioso, tem-se que:

as primeiras experiências em educação a distância foram singulares e isoladas. No entanto, já eram de profunda importância para as pessoas implicadas, porque o conteúdo era a religião e a controvérsia religiosa, que eram levadas muito a sério naquela época. Estou me referindo aqui a São Paulo, que escreveu suas famosas epístolas a fim de ensinar às comunidades cristãs da Ásia Menor como viver como cristãs em um 
ambiente desfavorável. Ele usou as tecnologias da escrita e dos meios de transporte a fim de fazer seu trabalho missionário sem ser forçado a viajar. (PETERS, 2012, p. 29)

Com as epístolas de São Paulo, observa-se, então, o desenvolvimento de uma abordagem mediada pela tecnologia, por meio da relação dos sujeitos com a sociedade de seu tempo, em que a linguagem vai se entrelaçando a essas tecnologias a fim de garantir possibilidades outras de ensino, para além da interação face a face.

De acordo com Guaranys e Castro (1979), o ano de 1728 é considerado um marco na história da EAD por ter sido na data de 20 de março deste ano que o professor Caleb Phillips fez um anúncio no jornal Boston Gazette, na cidade estadunidense de Boston, sobre o seu novo método de ensino de taquigrafia, com lições semanais enviadas por correspondência. Cem anos mais tarde, em 1833, há registros, na Suécia, no número 30 do periódico Lunds Weckoblad, de um curso de composição por correspondência oferecido pela antiga universidade sueca da cidade de Lund (HOLMBERG, 1995). Além disso, também na Suécia, encontram-se experiências com o uso da EAD, pelo Instituto Líber Hermones (PIVA JR et al., 2011).

Ainda conforme Holmberg (1995), na Inglaterra de 1840, encontram-se registros de uma tentativa de sistematização de um método de educação a distância desenvolvido por Isaac Pitman, o qual buscou ensinar taquigrafia por meio do uso de passagens bíblicas. As passagens eram reduzidas, de modo que coubessem em cartões postais que, posteriormente, seriam enviados para os estudantes pelos correios. Os estudantes deveriam transcrever as passagens e enviá-las de volta a Pitman para correção.

Segundo Guaranys e Castro (1979), partindo dessa experiência com o ensino de taquigrafia, foi no ano de 1843 que a Sociedade Fonográfica por Correspondência foi criada, com o intuito de se ocupar das correções dos exercícios taquigráficos, dando origem, por conseguinte, à instituição Colégios por Correspondência Sir Isaac Pitman.

Conforme Piva Jr et al. (2011, p. 2),

[...] no que se refere a um tipo de educação mais formal, é aproximadamente no ano de 1850 que o Reverendo W. Sewell, do Exeter College em Oxford, na Inglaterra (inserido num contexto educacional no qual se procurava descentralizar a Educação elitista de até então para um modelo baseado nas necessidades sociais), sugeriu o estudo fora do campus por meio de um sistema de palestras.

No que tange ao ensino de LE a distância, atribui-se ao ano de 1856 as primeiras experiências pioneiras nessa área, cujo surgimento se deu na Alemanha. Os principais expoentes dessa empreitada foram o francês Charles Toussaint e o alemão Gustav Langenscheidt, membro da Sociedade de Línguas Modernas de Berlim, que criaram uma instituição educacional em Berlim para ensinar idiomas por correspondência (GUARANYS; CASTRO, 1979; HOLMBERG, 1995).

Em 1858, a então Rainha do Reino Unido da Grã-Bretanha e Irlanda, Alexandria Victoria, popularmente conhecida como Rainha Victoria, assinou um documento que autorizava a universidade de Londres a fornecer certificados de aprendizagem a distância, 
tornando-se, assim, a primeira universidade no mundo a prover os estudantes com a oferta desse tipo de modalidade de qualificação (THOMPSON, 2016).

Em 1873, Anna Tickner fundou em Boston, Estados Unidos, a Society to Encourage Study at Home, cujo funcionamento se deu até o seu falecimento, no ano de 1897. Essa experiência consistia em proporcionar um intercâmbio mensal de cartas entre professor e aluno, por meio do envio de textos para leitura e testes de avaliação da aprendizagem, sendo sua clientela composta primordialmente por mulheres (GUARANYS; CASTRO, 1979).

Assim como na universidade de Londres, outras experiências acadêmicas com o ensino por correspondência foram se desenvolvendo pelo mundo, destacando-se, em especial, exemplos nos Estados Unidos, como: (a) a oferta de cursos por correspondência nas modalidades de graduação, mestrado e doutorado, no ano de 1874, pela Universidade de Wesleyan, embora seus títulos não tenham sido reconhecidos por outras universidades; (b) cursos por correspondência organizados por William Rainey Harper, para o Seminário Teológico Batista, para a escola de línguas de Chantagua e para a Universidade de Yale, em Illinois; (c) em 1882, em Ithaca, estado de Nova Iorque, cria-se a Universidade por Correspondência que, assim como a de Wesleyan, "não obteve licença estatal para outorgar títulos universitários, tendo curto tempo de existência" (GUARANYS; CASTRO, 1979, p. 11).

Mais tarde, em 1892, foi criado por William Rainey Harper, na Universidade de Chicago, o Departamento de Estudo por Correspondência, como parte da Divisão de Extensão dessa universidade. Esse Departamento ficou em funcionamento até 1964, ano em que seus cursos foram incorporados pela Universidade de Wisconsin (GUARANYS; CASTRO, 1979).

Ainda segundo Guaranys e Castro (1979), a experiência de Thomas J. Foster, em 1891, com a publicação de folhetos sobre segurança do trabalho em minas, com o intuito de oportunizar aperfeiçoamento aos trabalhadores, é considerada o embrião das Escolas Internacionais por Correspondência que, no ano de 1901, teve suas atividades formalizadas, na Pensilvânia, cuja expansão nos Estados Unidos e no exterior se deu em larga escala, tendo atendido a cerca de 7 milhões de alunos até 1965.

No Brasil, podemos citar o ano de 1904 como um relevante registro de experiência inicial com a EAD, por meio do curso de datilografia com materiais enviados pelos correios. Com o avanço da tecnologia, surgem, em 1920, os cursos para aprender português, francês e temas relacionados à radiodifusão, transmitidos pelas ondas de rádio e, a partir de 1960, destaca-se o aparecimento de iniciativas de EAD em projetos de ampliação do acesso à educação em território nacional brasileiro.

Para Tori (2010, p. 25, aspas do autor), ao longo da história, a EAD "tem sido tratada como uma modalidade diferente de educação, em contraposição à educação dita 'convencional', ou 'presencial'”. Entretanto, há estudiosos que preferem levar em conta o aspecto do ensino a distância, preservando-se o contato dos estudantes com os colegas e com o professor, em detrimento da perspectiva que leva em conta, no escopo da EAD, experiências de aprendizagem em que o estudante não adquire contato com outros indivíduos, estudando de modo isolado. 
É nesse sentido que Josias R. Hack entende a EAD como:

[...] uma modalidade de realizar o processo de construção do conhecimento de forma crítica, criativa e contextualizada, no momento em que o encontro presencial do educador e do educando não ocorrer, promovendo-se, então, a comunicação educativa através de múltiplas tecnologias. (HACK, 2011, p. 39)

Para Paiva (1999), enquanto concepção educativa, a EAD deve ser entendida como um processo que envolve meios de comunicação que nos permitem ir além dos limites de tempo e espaço, tornando acessível, dessa forma, "a interação com as fontes de informação e/ou com o sistema educacional de forma a promover a autonomia do aprendiz através de estudo independente e flexível" (PAIVA, 1999, p. 41).

Neste trabalho, estamos considerando a EAD sob uma perspectiva ampla, contemplando, dessa forma, toda e qualquer oportunidade de aprendizagem que se efetiva fora do ambiente de sala de aula convencional, presencial, com ou sem o contato direto/indireto com o professor e outros participantes, por meio do uso de materiais de ensino e aprendizagem variados, disponibilizados em diferentes suportes.

Passando pelos materiais impressos enviados pelos correios, pelo surgimento dos slides de projeção de imagens aliados a aparatos audiovisuais como material de suporte, pela utilização do rádio para transmissão de conteúdos, pela invenção do aparelho de televisão - que desempenhou papel crucial no desenvolvimento de práticas de EAD, por meio de experiências com os telecursos -, até chegar ao uso do computador e da Internet, pode-se afirmar que todas essas iniciativas têm contribuído bastante para a constituição de processos de ensino e aprendizagem de LE em diversos países do mundo, assim como em nosso país, como veremos no decorrer.

\subsection{Experiências em EAD no Brasil: correspondência, rádio e televisão}

De acordo com Paiva (1999), as experiências envolvendo a EAD, ao longo do tempo, podem ser divididas em cinco fases. Na primeira, encontram-se os cursos que fazem uso, exclusivamente, de material impresso, os populares cursos por correspondência.

$\mathrm{Na}$ seguna fase, aparecem as experiências de ensino por transmissões radiofônicas. Já na terceira fase, começam a surgir experiências que agregavam ao material impresso as mídias de áudio e vídeo, destacando-se nessa época os programas educativos exibidos pela televisão.

Na quarta fase, podemos destacar, nos anos 1990, o surgimento dos computadores que tiveram suas funções potencializadas com o aparecimento da Internet, cuja propagação e uso, consideravelmente rápido, em ampla escala, deu origem ao que Paiva chamou de quinta fase da EAD, ou a fase da aprendizagem flexível.

É importante destacar que, conforme bem nos lembram Piva Jr et al. (2011), no Brasil, o interesse pela EAD é impulsionado pelo desenvolvimento das ditas tecnologias 
da informação e comunicação, aliado à explosão do fenômeno internet. Os autores citam, inclusive, que durante muito tempo as experiências com a EAD estiveram marginalizadas, representando o que eles chamam de "a periferia dos sistemas de Educação, destinados à camada mais pobre e menos instruída da população" (PIVA JR et al., 2011, p. 15).

Se em determinada época o enfoque da EAD estava atrelado ao provimento de cursos profissionalizantes, é correto afirmar que hoje em dia, no entanto, sua oferta se extende a diferentes níveis e modalidades de ensino e aprendizagem. A esse respeito, de acordo com Mugnol (2009, p. 336):

no início do século XX, [a EAD] tornou-se uma modalidade de ensino capaz de atender a todos os níveis, incluindo programas formais de ensino, aqueles que oferecem diplomas ou certificados e programas de caráter não formais, cujo objetivo é oferecer capacitação para a melhoria no desenvolvimento das atividades profissionais.

Como já mencionado, o ano de 1904 representa um marco inicial em se tratando da experiência com a EAD no Brasil, tal que é possível encontrar neste período, por exemplo, registros de anúncio, nas páginas de classificados do Jornal do Brasil, de um curso de datilografia por correspondência. No entanto, segundo afirma Alves (2007), pesquisas oriundas de diversas fontes dão conta de mostrar que existem registros em jornais de circulação no Rio de Janeiro, anteriores ao ano de 1900, cujos anúncios também se referem à oferta de cursos de profissionalização por correspondência.

Considerando a principal capital do país, pode-se dizer que por lá, no jornal O Estado de S. Paulo (Estadão), de 1909 em diante, tornou-se comum encontrar em seus classificados anúncios de cursos profissionalizantes por correspondência, como se observa em:

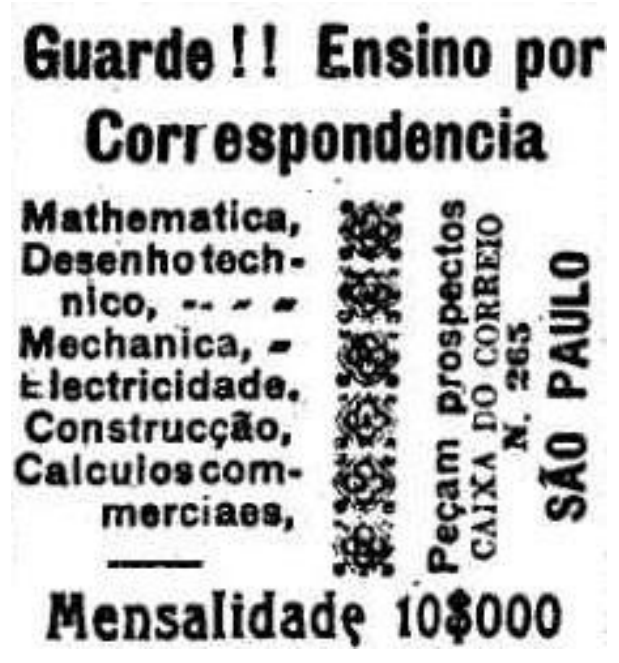

Figura 1. 0 Estado de S. Paulo - 25/3/1909. Fonte: http://acervo.estadao.com.br/imagens/105x65/1909.03.25.jpg. 
Em se tratando do ensino por correspondência, nota-se que há uma relação bastante comum entre o seu uso apoiado sobre outras tecnologias. A esse respeito, cabe trazer à baila a fala de Guaranys e Castro $(1979$, p. 5) quando afirmam que:

O ensino por correspondência pode ser analisado em dois contextos distintos: como uma tecnologia de ensino utilizada de forma autônoma e independente, ou como parte de um conjunto de multimeios, isto é, associada a outros meios educativos como o rádio, a televisão etc.

Nos anos 20, já era possível encontrar registros no Brasil de cursos transmitidos pelas ondas de rádio, a grande novidade em termos de tecnologia naquela época. Nesse período, os estudantes faziam uso de material impresso para estudar português, francês, bem como conteúdos ligados à radiodifusão.

De acordo com Alves (2007), o contexto de aprendizagem mediado pelo rádio pode ser considerado um dos principais meios de transmissão de informação e construção de conhecimento depois do contexto de uso da correspondência para esse fim, tal que um número significativo de programas foram sendo implantados com a criação do Serviço de Radiodifusão Educativa do Ministério da Educação, em 1937.

Segundo Gomes (2011, p. 39, grifo da autora):

é importante lembrar que foi por meio do rádio que programas educativos contribuíram de forma significativa na produção do conhecimento para milhares de pessoas no mundo todo e no Brasil. O responsável por esse feito no Brasil foi Edgard Roquette Pinto, da Academia Brasileira de Ciências, que criou a pioneira Rádio Sociedade do Rio de Janeiro, com o intuito de difundir a educação em meados de 1923. Já nessa época os anúncios dos cursos a distância convidavam o cidadão a participar de um curso técnico em suas horas de folga, no aconchego da sua casa.

Essa Rádio, de iniciativa privada e cujo funcionamento, em um primeiro momento, se deu nas dependências de uma escola superior mantida pelo Poder Público, foi doada para o Ministério da Educação e Saúde em 1936, em virtude de pressões políticas da época (ALVES, 2007).

Em 1939, foi criado o Instituto Monitor ${ }^{2}$, ou ainda, Instituto Técnico Rádio Monitor, reconhecido como uma instituição pioneira no Brasil no que concerne à oferta da EAD. A instituição teve início com a instalação de um pequeno negócio na região central de São Paulo, pelo imigrante húngaro Nicolás Goldberger, que chegou ao país trazendo o seu conhecimento técnico em eletrônica. Conforme Gomes (2011, p. 40):

[...] Naquela época, as apostilas de curso eram enviadas pelo correio juntamente com os materiais necessários para que o cursista pudesse colocar em prática os ensinamentos da apostila. Um exemplo seria um curso de técnico em montagem de rádio. Além da apostila, as ferramentas e as peças para a montagem de um rádio eram enviadas pelo correio para o aluno. Já naquela ocasião, a soma de duas

\footnotetext{
${ }^{2}$ Para maiores detalhes, conferir o endereço eletrônico: https://www.institutomonitor.com.br/.
} 
tecnologias era utilizada para a EAD: o correio e o rádio. Essa forma de ensinar já acontecia na Europa e nos Estados Unidos.

Nessa mesma perspectiva, cita-se o Instituto Universal Brasileiro ${ }^{3}$ fundado no estado de São Paulo, em 1941 (GUARANYS; CASTRO, 1979). Essas entidades desempenharam papel fundamental junto ao processo formal de formação profissionalizante, cujos contextos foram delineados por oportunidades bastante produtivas de capacitação de brasileiros para o mercado de trabalho, atendendo à demanda crescente de mão de obra no âmbito da educação profissional de nível básico (ALVES, 2007). Frisa-se, aqui, que ambas as instituições se mantêm em atividade até hoje, porém, agregando novas tecnologias para atender às demandas da contemporaneidade, fazendo uso não apenas de material impresso, mas, sobretudo, provendo cursos em suporte on-line.

$\mathrm{Na}$ década de 70, configura-se como iniciativa bem-sucedida de EAD a modalidade de ensino via aparelhos de televisão - teleducação. De acordo com Piva Jr et al. (2011, p. 11), “em 1976, foi criado o Sistema Nacional de Teleducação e o SENAC também aproveitou as novas tecnologias de então para a disseminação de cursos instrucionais". No dia 16 de janeiro de 1978, foi ao ar a primeira aula do Telecurso $2^{\circ}$ grau, promovido pela Fundação Padre Anchieta (TV-Cultura), em convênio com a Rede Globo de Televisão, por meio da Fundação Roberto Marinho, como podemos observar em:

\section{TV inicia curso de $2^{\circ}$ grau \\ Ao partlcipar ontem da inau- guraçăo oficlal do Telecurso $2 \%$ grau, realizado pela Fundaçăo Padre Anchieta (TV-Cultura), em convenio com a Rede Globo de Televisăo, o secretário esta- dual da Educação, José Bonifá. cio Coutinho Nogueira, lembrou que "a grande deficiência está

\begin{abstract}
no ensino de 1: grau, onde de 700 mil alunos, apenas $200 \mathrm{mil}$ chegam à 8 s sérte". Depols de falar que o Telecurso vem auxillar a solucionar o problema educa. clonal brasileiro, o secretário reiterou: "Enquanto năo resolvermos o problema da evasåo do 1: grau, năo resolveremos nada."
\end{abstract} \\ As transmissőes do Telecur- so, Inicladas ontem às 6 e $45 \mathrm{e}$ às 8 horas pelo canal 5 e as 13 e 30 pelo canal 2, pretendem alcan- çar uma populaçăo escolar esti- mada em $400 \mathrm{mil}$ pessoas. Ini- cialmente, ele sera transmitido apenas no Bstado de 84o Paulo, mas os planos incluem as de- mais regiōes do Pais.}

Figura 2. O Estado de S. Paulo - 17/1/1978. Fonte:

http://acervo.estadao.com.br/imagens/105x65/1978.01.17.jpg.

Pode-se afirmar que um dos projetos mais difundidos de ensino por meio do uso da televisão, na modalidade de video-aulas, é o antigo Telecurso 2000, que já se chamou Novo Telecurso e, atualmente, é caracterizado apenas como Telecurso.

Cabe salientar que o Telecurso surgiu, como se percebe pelo fragmento em destaque (figura 2), com o objetivo de suprir uma lacuna na formação do brasileiro, ousando, dessa maneira, "auxiliar a solucionar o problema educacional" do nosso país. Entretanto, presume-se que apesar de suas ações estarem pactuadas com a proposta de diminuição da defasagem idade-ano, com o provimento de práticas de Educação de Jovens e Adultos (EJA), e com a possibilidade de se configurar, de fato, em uma

\footnotetext{
${ }^{3}$ Para maiores detalhes, conferir o endereço eletrônico: http://www.institutouniversal.com.br/.
} 
alternativa viável ao ensino regular em municípios e comunidades distantes, entende-se que ainda há muito por se fazer no âmbito da educação brasileira, cabendo ao Estado implementar políticas públicas efetivas para dar conta dessa questão.

O projeto, criado e mantido pela Fundação Roberto Marinho, é estruturado em um formato que fornece material de estudo para a educação básica, por meio de apostilas, material impresso (figura 3), ou de programas de televisão exibidos em canais abertos brasileiros. O conteúdo é utilizado em diversas telessalas em várias partes do país, o qual já teve, inclusive, apoio da Federação das Indústrias do Estado de São Paulo (FIESP). Estima-se que cerca de 32 mil salas de aula com a metodologia telessala tenham sido implementadas em todo Brasil, desde 1995, pela Fundação Roberto Marinho, por meio de parceriais com órgãos municipais, estaduais, escolas públicas e privadas.

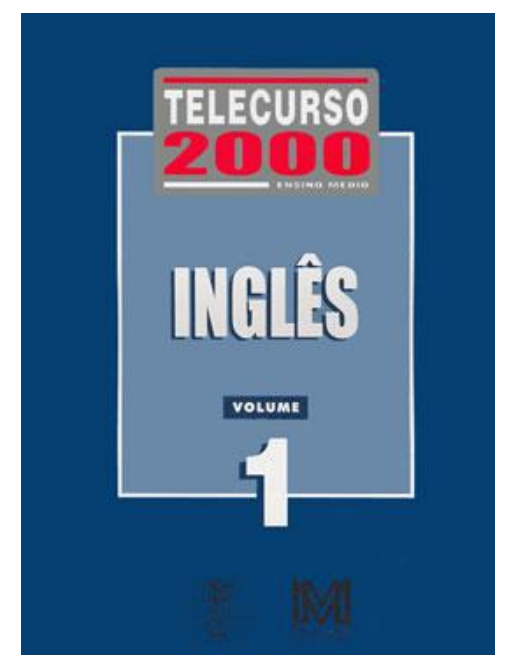

Figura 3. Inglês - Volume 1 - Telecurso 2000. Fonte: http://img.martinsfontespaulista.com.br/lmagens/produtos/16/250016/250016_Ampliada.jpg.

Ainda no que toca à metodologia Telessala, pontua-se que nas salas de aula, os estudantes têm a oportunidade de assistir às teleaulas junto com um professor que tenha sido formado por meio dessa metodologia. $\mathrm{O}$ professor desenvolve atividades com os estudantes durante os encontros, com o objetivo de auxiliá-los a concluir o ensino fundamental e/ou médio (TELECURSO 2000, s/ano).

Para Gomes (2011), os aparelhos de televisão contribuíram substancialmente para o aumento da oferta de cursos na modalidade EAD. Presume-se, assim, que a televisão alcançou a posição de uma das mais importantes tecnologias nas décadas de 80 e 90 enquanto propulsora de práticas inovadores na área educacional, culminando com a produção de material didático específico para o uso desse suporte em contextos de aprendizagem. 


\subsubsection{Material audiovisual interativo: publicações editoriais seriadas}

Inegavelmente, existe, hoje em dia, uma miríade de materiais de suporte ao ensino e à aprendizagem disponíveis no mercado, tanto na versão impressa como na versão online, gratuitamente ou não, para se aprender/estudar/praticar uma LE.

Voltando um pouco no tempo, provavelmente, muitos estudantes ficariam surpresos se descobrissem que as fitas cassetes e de VHS, revistas e jornais, foram as principais e, muitas vezes, únicas fontes de acesso ao idioma alvo daqueles que se dedicavam a estudar inglês em um passado remoto.

Nesse contexto, consolidou-se, com grande proliferação no cenário brasileiro, a produção e vendagem em massa de materiais interativos de áudio (fitas e mais tarde CDs) e vídeo (VHS e mais tarde DVDs), em pacotes seriados que incluem apostilas/livros impressos, produzidos por editoras nacionais. Com esse formato se desenvolveram experiências de aprendizagem autônoma, por meio das quais o estudante constrói conhecimento a partir do uso de material audiovisual interativo seriado, produzido por empresas editoriais.

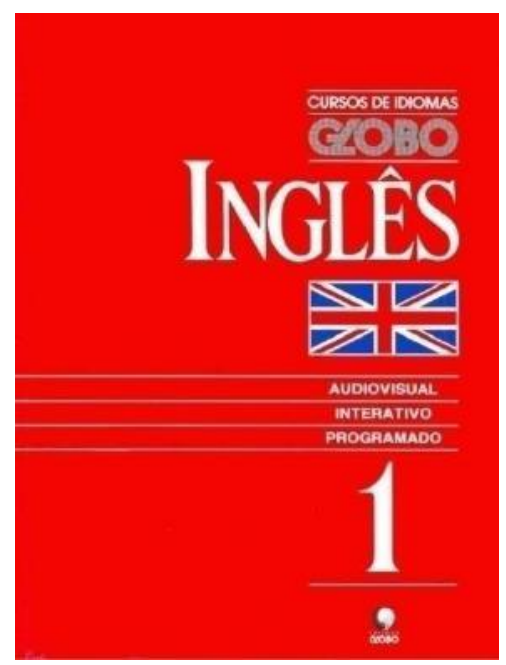

Figura 4. Curso de Idiomas Globo. Fonte:

https://image.slidesharecdn.com/cursodeidiomasgloboinglslivro001-110617102951-phpapp01/95/curso-deidiomas-globo-ingls-livro-001-1-728.jpg?cb=1308306685.

A figura 4 ilustra um dos materiais de maior alcance de público e tiragem, em virtude da divulgação, inclusive, por meio de comerciais de TV. Os Cursos de Idiomas Globo, material composto por fascículos, com áudios gravados para ensinar pronúncia e conversação, tornaram-se populares na oferta de cursos de idiomas.

No início do projeto, a obra poderia ser adquirida nas bancas de jornais e revistas, pessoalmente dirijindo-se aos endereços da Editora Globo em São Paulo ou Rio de Janeiro, ou por meio de carta enviada diretamente à editora. Atualmente, é possível ter acesso às edições antigas por meio de sites que comercializam produtos usados. Trata-se, portanto, de uma obra audiovisual interativa, publicada em vinte e sete edições semanais, em que cada material é constituído por sessenta e quatro páginas, cujas lições são 
acompanhadas por material de áudio em fitas cassete para ser trabalhado em casa pelo estudante no decorrer de cada lição.

Numa relação de aproximação com os materiais desenvolvidos para o ensino por correspondência, assume-se que os materiais seriados têm em comum com esta modalide de ensino o fato de que ambas colocam o foco na aprendizagem por parte do estudante. Para Guaranys e Castro (1979, p. 23), essa é a principal característica do ensino por correspondência e, muitas vezes, esquecida. "Trata-se, antes de tudo, de um processo educativo". Hoje, há várias iniciativas no mercado com oferta de material impresso audiovisual que alia esse tipo de metodologia ao uso de componentes tecnológicos disponibilizados na Internet.

\subsubsection{Ensino e aprendizagem de inglês pela Internet: aprendizagem flexível}

Como observado até então, as oportunidades de EAD em diferentes contextos de aprendizagem se basearam não só em materiais impressos, mas, sobretudo, acompanharam e têm incorporado, além do rádio, TV e vídeo, as novas tecnologias da informação e comunicação, fazendo uso de aparelhos tecnológicos digitais, como, por exemplo, os dispositivos de telefonia móvel.

"Porém, é com a inserção e crescimento da internet no meio educacional que se verifica uma enorme mudança na maneira de se fazer Educação a Distância" (PIVA Jr et al., 2011). De acordo com Peters (2012), uma das razões pelas quais a EAD tem ganhado importância pelo mundo se refere a sua relação estrutural com as experiências variadas com a aprendizagem on-line.

Em se tratando do ambiente on-line, ou virtual, há estudos recentes que analisam, inclusive, o potencial das redes sociais junto ao ensino de línguas (ARAÚJO; LEFFA, 2016). De acordo com Finardi e Porcino (2016), redes sociais, como o Facebook, por exemplo, têm se mostrado ser ambientes produtivos de ensino e aprendizagem de LE, destacando-se, especialmente, a sua capacidade de possibilitar a socialização, a interação e a comunicação entre os usuários, que tendem a se beneficiar mutuamente.

As estudiosas ressaltam, entretanto, que apesar das experiências exitosas, evidencia-se o fato de que os estudantes estão utilizando bem mais a Internet e o Facebook, tornando-se mais autônomos na busca por informação e prática em inglês, do que os professores, que deveriam buscar maneiras produtivas, inovadoras e criativas de agregar as redes sociais as suas prática pedagógicas.

Para Dantas (2012), ao propor atividades pedagógicas, por meio do uso da modalidade on-line, o professor deve estar atento aos estilos de aprendizagem dos estudantes, tendo em vista que "a compreensão dos estilos de aprendizagem na modalidade on-line está diretamente ligada à forma como o aluno aprende, e como é capaz de melhorar seu desempenho para aplicação na vida pessoal e profissional" (DANTAS, 2012, p. 115).

Silveira (2015) reflete sobre o papel de cada recurso tecnológico a ser utilizado com finalidade pedagógica para o desenvolvimento das habilidades linguísticas dos 
estudantes no ensino de inglês a distância, destacando a relevância do professor zelar pelo bom planejamento, refletindo, analisando e reavaliando a pertinência das ferramentas utilizadas junto ao processo de ensino e aprendizagem de LE na EAD.

No que tange aos sites especializados em ensino de inglês on-line, algumas iniciativas têm se destacado ao longo das duas últimas décadas, tal que se pode afirmar que um dos principais expoentes do ramo, já há alguns anos, tem sido a EF English Live ${ }^{4}$. A marca, referenciada como escola de inglês on-line, foi criada em 1996, com o nome de Englishtown, com o propósito de auxiliar os alunos que não tinham tempo de frequentar aulas em ambiente presencial a aprender inglês.

A escola integra o grupo EF Education First, com 50 anos de experiência no mercado de ensino de idiomas, com escolas físicas, e variados programas de intercâmbio. No Brasil, a marca já opera há mais de 15 anos, com uma excelente aceitação por parte do público-alvo, qual seja: alunos interessados em aprender inglês, por meio do uso da tecnologia. Ainda, considerando o contexto brasileiro, por meio de investimento do Governo Federal, tem-se, atualmente, o My English On-line (MEO), configurando-se como um curso baseado na ferramenta para ensino de idiomas $M y E L T^{5}$, por meio da qual se é possível ter acesso a um pacote completo de atividades interativas que tendem a favorecer a aprendizagem de inglês em qualquer lugar e a qualquer hora.

O MEO é uma iniciativa do Ministério da Educação (MEC) e da Coordenação de Aperfeiçoamento de Pessoal de Nível Superior (Capes), desenvolvido pelo setor educacional da National Geographic Learning em parceria com a Cengage Learning, constituindo-se, assim, como um curso de inglês do Idiomas sem Fronteiras (IsF), cuja oferta se dá em ambiente virtual. O MEO tem se popularizado como um curso oferecido pela CAPES/MEC, no âmbito da oferta de ensino de inglês em território nacional, para professores e alunos de universidades e institutos federais, além de contemplar as universidades privadas, com o intuito de ampliar as possibilidades de desenvolvimento de uma política linguística efetiva em solo brasileiro, com vistas ao fortalecimento de uma política de internacionalização do ensino e da pesquisa brasileira.

\section{Funcionamento discursivo à luz de preceitos da semântica global}

Assentando-se sobre a AD de base enunciativa, nosso interesse com este trabalho é analisar o funcionamento discursivo de um conjunto de enunciados que recuperam dizeres acerca do ensino e da aprendizagem de inglês em diferentes contextos de EAD em nosso país.

Dessa maneira, à luz da semântica global (MAINGUENEAU, 2008), objetiva-se dar a ver os sentidos postos em circulação sobre aprender inglês nesses cenários, com vistas a engendrar um campo de interlocução entre conceptualizações que aproximam linguagem e tecnologia sob a lente de uma perspectiva discursiva.

\footnotetext{
${ }^{4}$ Para maiores detalhes, conferir o endereço eletrônico: https://englishlive.ef.com/pt-br/sobre-nos/.

${ }^{5} \mathrm{O}$ MyELT é um sistema de ensino e aprendizagem mediado pelo computador, por meio do acesso à internet, desenvolvido pela equipe da National Geographic. Para maiores detalhes, acessar: https://myelt.heinle.com/ilrn/global/aboutMyelt.do.
} 
De acordo com os pressupostos da semântica global, todos os elementos envolvidos na produção e circulação dos sentidos devem ser levados em conta no âmbito da análise do campo semântico de determinado funcionamento discursivo, tendo em vista que suas dimensões estão imbricadas e organizadas em um sistema de restrições que só fazem sentido se tomadas sob esse conjunto.

Isso requer dizer que:

um procedimento que se funda sobre uma semântica 'global' não apreende o discurso privilegiando esse ou aquele dentre seus 'planos', mas integrando-os todos ao mesmo tempo, tanto na ordem do enunciado quanto na da enunciação. (MAINGUENEAU, 2008, p. 75, aspas do autor)

É sob essa perspectiva que buscamos analisar nossa materialidade linguística enquanto um conjunto que investe o discurso em suas múltiplas dimensões (MAINGUENEAU, 2008). Desse maneira, nosso recorte prioriza enunciados postos em circulação em mídias impressa e/ou virtual, atravessados por dizeres de ordem sóciohistórica, ideológica, que tendem a dar a ver os sentidos veiculados sobre aprender inglês em diferentes épocas, por meio de variados instrumentos e suportes. Para esse procedimento de análise, mobilizaremos, especialmente, as seguintes dimensões: o vocabulário; e os temas (MAINGUENEAU, 2008). Interessa-nos, aqui, abarcar os diferentes elementos que constituem a semântica discursiva desse funcionamento enunciativo, entendendo que:

[...] o conjunto de elementos semânticos habitualmente usado nos discursos de uma dada época constitui a maneira de ver o mundo numa dada formação social. Esses elementos surgem a partir de outros discursos já construídos, cristalizados e cujas condições de produção foram apagadas. [...] A semântica discursiva é o campo da determinação ideológica propriamente dita. (FIORIN, 1998, p. 19)

Presume-se, assim, que, no seio desse conjunto, a escolha do vocabulário não se dá de modo aleatório, integrando, em lugar, todo um conjunto de regularidades que compõe os sistemas de restrições semânticas próprias do funcionamento discursivo, contribuindo para a instauração de um modo de dizer, pois "entre vários termos a priori equivalentes, os enunciadores serão levados a utilizar aqueles que marcam sua posição no campo discursivo" (MAINGUENEAU, 2008, p. 81). Em se tratando dos temas, assume-se que:

tema é o elemento semântico que designa um elemento não-presente no mundo natural, mas que exerce o papel de categoria ordenadora dos fatos observáveis. São temas, por exemplo, amor, paixão, lealdade, alegria. (FIORIN, 1998, p. 24)

Pode-se dizer, então, que ao se referir a elementos semânticos que indicam coisas que em si não têm existência no mundo natural, essa construção se faz por meio de enunciados que mobilizam vocabulários que operam no fio discursivo, atentando, no entanto, para o fato de que a palavra e o tema não se configuram como unidades de análise pertinentes se tomados por eles mesmos. Ou seja, o que está em jogo, aqui, não é a apreensão desses elementos de modo isolado, em seu sentido literal, deslocado do contexto de enunciação, mas o seu tratamento semântico no bojo de determinado 
funcionamento discursivo, por meio do qual ele se constitui como um elemento indissociável, e é disso que trata a semântica global (MAINGUENEAU, 2008).

Os vocabulários e temas que nos interessam neste trabalho são elementos que atravessam enunciados inscritos em uma gama de textos de divulgação sobre cursos de inglês em diferentes contextos de EAD, a saber: folhetos e panfletos (recuperados por meio da Internet). Além disso, considera-se também os aspectos sócio-históricos envolvidos nesses contextos em que a aprendizagem de LE (inglês) se dá, tendo em vista que, para a semântica global, todas as dimensões que se relacionam com a produção e circulação dos sentidos devem ser levados em conta no âmbito da análise do campo semântico de determinado funcionamento discursivo.

Nessa perspectiva, tendo em vista que nossa análise se dá com base em enunciados materializados sob a forma de textos específicos, entendemos ser este um empreendimento teórico que, de fato, tende a nos auxiliar a observar e entender quais são os sentidos veiculados sobre ensinar e aprender inglês, inscritos em uma gama de textos, que recuperam diferentes contextos de EAD, considerando sobremaneira as condições específicas de produção.

\subsection{Aprender inglês em diferentes contextos de EAD: circulação de sentidos}

Desde o surgimento dos primeiros cursos livres de idiomas no Brasil, na década de 1930, que o discurso sobre a necessidade de se aprender a falar inglês em nosso país tem sido disseminado. Entretanto, não podemos desconsiderar o papel desempenhado pelos cursos por correspondência, a partir da década de 1940, no que tange à inserção desse idioma em experiências não formais de aprendizagem no Brasil, aquelas que se realizam fora dos muros escolares.

Pode-se afirmar que traçar um panorama do ensino de LE em qualquer perspectiva nos conduz, de certa forma, a dissertar sobre que conceito de língua está implicado nesse processo de ensino e aprendizagem, tendo em vista que ele tende a nortear o tipo de abordagem que se inscreve no material a ser utilizado. Em face dessa questão, presumese dizer que nos materiais impressos fornecidos pelos cursos por correspondência a língua era provavelmente vista como estrutura gramatical.

Isso revela um aspecto importante e, ao mesmo tempo, limitado do processo de ensino e aprendizagem de LE por meio dos materiais enviados pelos correios à época recursos tecnológicos impressos que os estudantes deveriam utilizar para aprender o idioma alvo com ênfase, basicamente, no aspecto estrutural da língua (gramática), e na leitura. Esse tipo de abordagem, portanto, teria como princípio colocar o foco da aprendizagem no sistema abstrato de regras, desconsiderando o caráter comunicativo da linguagem, a língua em uso a partir das suas mais variadas possibilidades de interação na vida social, por meio dos recursos linguístico-discursivos postos em operação pelos falantes de determinada comunidade linguística. Infere-se, assim, que leitura e escrita estariam no centro das práticas de aprendizagem de inglês pautadas no uso de material impresso dos cursos por correspondência. 
Por outro prisma, de acordo com Oliveira (2014), tentar compreender a razão pela qual os brasileiros precisam estudar inglês parece ser algo óbvio. Essa alegação traz no bojo o fato de que a aprendizagem desse idioma tem sido tão amplamente divulgada "por meio de anúncios publicitários e pelo currículo escolar que já tomou contorno de senso comum, [...] [naturalizando-se] na mente dos brasileiros" (OLIVEIRA, 2014, p. 60).

Pode-se afirmar que se trata, pois, de um conjunto de enunciados propagados ao longo dos tempos, atravessados por formações ideológicas pactuadas com um projeto engendrado por agências governamentais britânicas e estadunidenses, com o intuito de fomentar o expansionismo da cultura anglófona em nosso país, por meio da penetração político-ideológica materializada em símbolos culturais, como, por exemplo, a língua (SOUZA, 2016). Em outras palavras, para Oliveria (2014, p. 61), trata-se de "um processo histórico atrelado ao imperialismo econômico da Inglaterra e dos Estados Unidos", particularmente.

Entende-se aqui por formação ideológica:

[...] a visão de mundo de uma determinada classe social, isto é, um conjunto de representações, de ideias que revelam a compreensão que uma dada classe tem do mundo. [...] a cada formação ideológica corresponde uma formação discursiva. (FIORIN, 1998, p. 32)

Ao analisar folhetos de anúncios que ofereciam cursos por correspondência em inglês na década de 1940, observa-se que essas formações ideológicas se manifestam semanticamente por meio de elementos que se vinculam ao tema da prosperidade, filiando-se, por conseguinte, a um funcionamento discursivo que prega a filosofia do aprender inglês, por meio de estruturas gramaticais, para se obter sucesso na vida, como se pode ver na figura 5 .

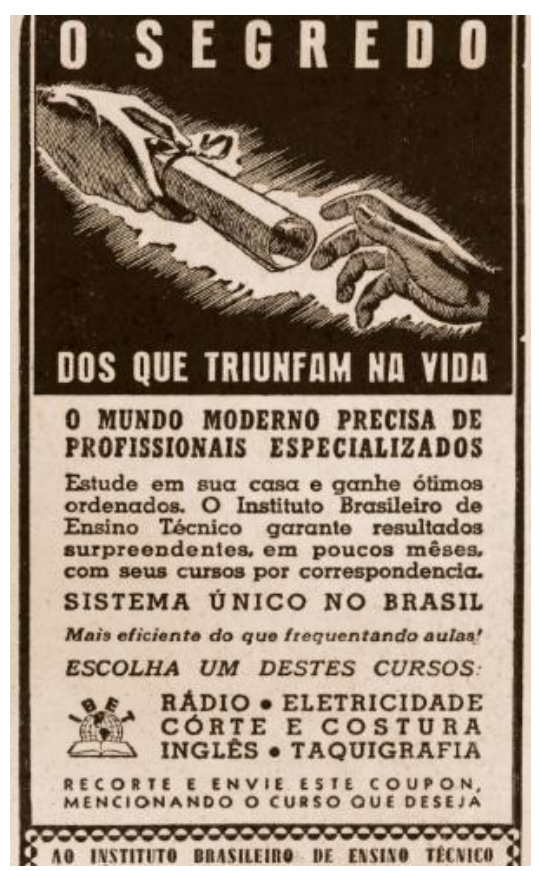

Figura 5. Instituto Brasileiro de Ensino Técnico anúncio da década de 1940. Fonte: http://imguol.com/2012/04/16/0-instituto-brasileiro-deensino-tecnico-tambem-oferecia-cursos-tecnicos-detaquigrafia-e-de-ingles-1334588541638 300x500.jpg. 
Ainda que a dimensão tema seja um elemento caro em nossa análise, torna-se imprescindível frisar, de antemão, que "é por sua formação discursiva e não por seus temas que se define a especificidade de um discurso" (MAINGUENEAU, 2008, p. 84). Assim, ao recortar o material linguístico a ser investigado neste trabalho, nota-se que o tema da prosperidade está presente em anúncios de cursos por correspondência ao longo das décadas de 1940-1980, inscrevendo no fio enunciativo, por meio da materialidade linguística, elementos semânticos que visam a criar um efeito de verdade sobre o fato de se aprender inglês para se obter sucesso ao longo de sua existência.

Em meio a essa regularidade, junto ao processo de significação do que se entende por aprender inglês nesses recortes, é que se pode afirmar que quem aprende inglês estuda as estruturas da língua com o intuito de se tornar um indivíduo capaz de "triunfar na vida" (figura 5), o que requer colocar em circulação uma gama de textos repletos de unidades semânticas que se articulam a formações discursivas em operação nessa interdiscursividade. Por essa perspectiva é que se pode assumir que:

[...] o texto não é um estoque inerte que basta segmentar para dele exrair uma interpretação, mas inscreve-se em uma cena enunciativa cujos lugares de produção e de interpretação estão atravessados por antecipações, reconstruções de suas respectivas imagens, imagens estas impostas pelos limites da formação discursiva. (MAINGUENEAU, 1997, p. 91)

Ainda quanto aos enunciados postos em circulação por meio do folheto em destaque na figura 5, afirma-se que contribuem para a naturalização desse efeito de verdade a utilização de modos de enunciar como: "o mundo moderno precisa de profissionais especializados"; "estude em sua casa e ganhe ótimos ordenados". Infere-se, assim, que o profissional especializado é aquele que fala inglês e, com essa qualificação profissional, maiores são as chances de se aumentar a renda familiar, transformando a sua vida em prosperidade e bem-estar.

Para além da ampliação do ordenado, "estudar em casa", nesse contexto, referese ao tema de uma pretensa flexibilidade atribuída a esse tipo de curso, a qual tenta fortalecer o discurso de que se pode aprender sem o contato direto com o professor e os colegas de classe, sem recorrer ao ensino presencial, como reforçado pelo seguinte enunciado: "mais eficiente do que frequentando aulas!" (figura 5).

Além disso, destaca-se também a ênfase dada ao discurso de que cursos de sucesso são aqueles em que os alunos aprendem inglês em pouco tempo, como observado pelo trecho: "O Instituto Brasileiro de Ensino Técnico garante resultados surpreendentes, em poucos meses, com seus cursos por correspondência" (figura 5).

Vejamos o folheto seguinte. Na figura 6, observa-se a manutenção desse tipo de formação ideológica que atravessa dizeres que fazem eco ao sucesso a ser atingido por meio da aprendizagem de inglês, tal que se torna possível ganhar dinheiro. Por conseguinte, vencer na vida tende a ser o destino inevitavelmente alcançado. 


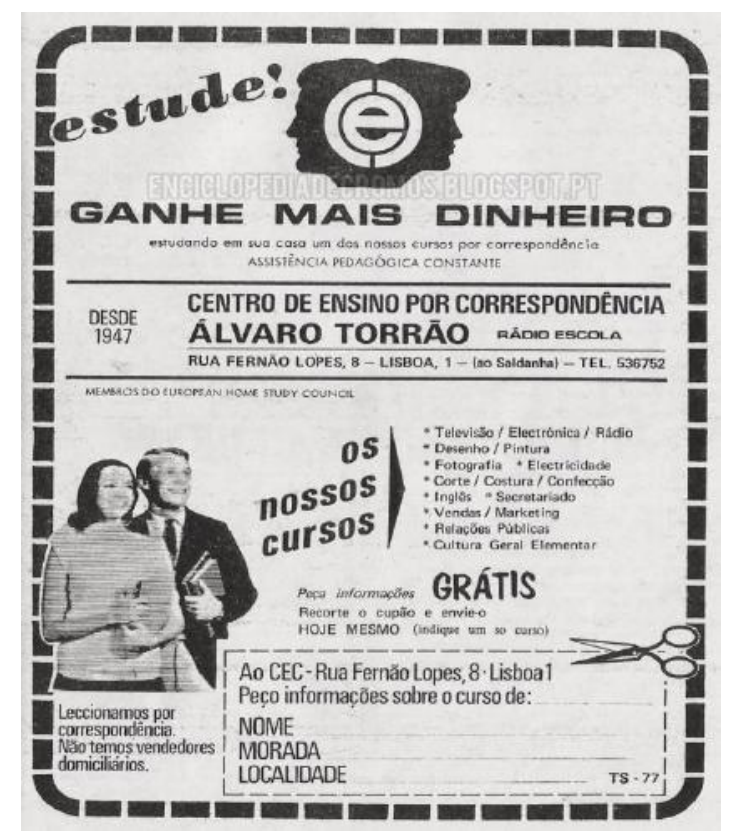

Figura 6. Centro Ensino por Correspondência Álvaro Torrão.

Fonte: Folheto retiradoda Revista Tele Semana $n^{0} 77$, de 12 de julho de 19746.

Ainda nessa perspectiva de fortalecer o discurso de que se aprende inglês para se ganhar dinheiro e crescer na vida, tem-se o seguinte anúncio:

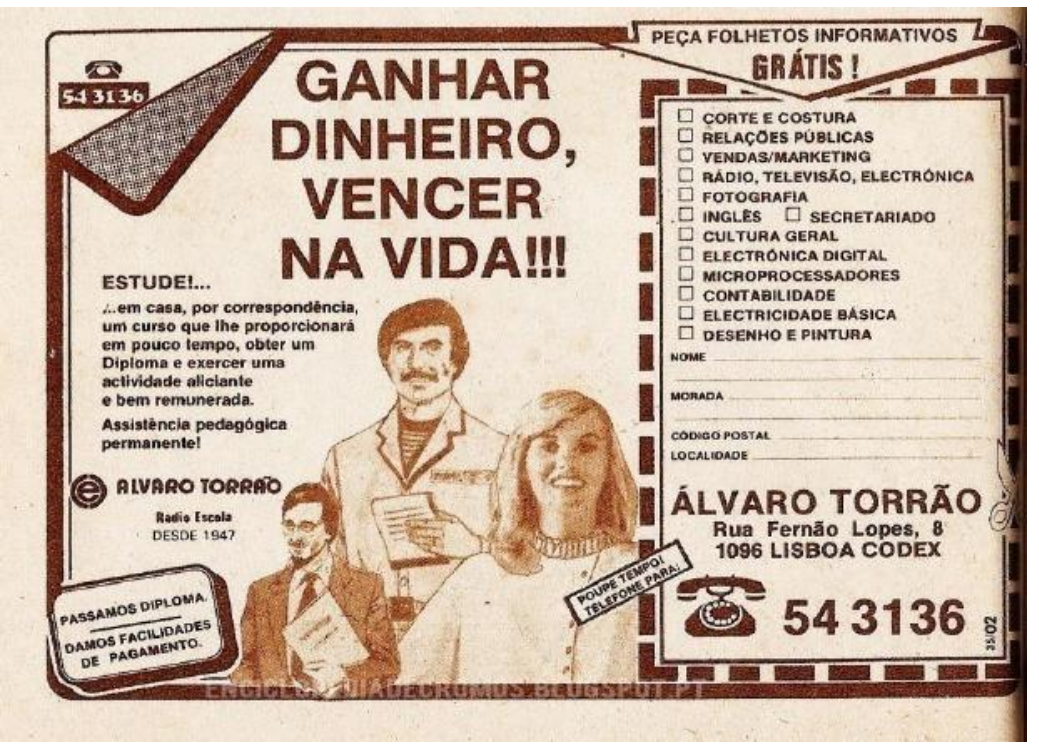

Figura 7. Curso por Correspondência Álvaro Torrão.

Fonte:Anúncio retirado da revista Crónica Feminina, n 1482, de 18 de abril de 19857.

6 Esse folheto também pode ser encontrado por meio da página: http://3.bp.blogspot.com/ZF7nmKCnu2k/UtpGq1Q_z4I/AAAAAAAAUBw/woIkN8G4fWE/s1600/pub06_centroensinocorrespond enciaalvarotorrao_01.jpg. Acesso em 15 ago. 2016.

7 Esse folheto também pode ser encontrado por meio da página: http://3.bp.blogspot.com/wIcjuOFKIbY/UOSE0T5X2dI/AAAAAAAAPrM/dyemP4K7chY/s1600/34cursosalvarotorrao.jpg.

Acesso em 10 ago. 2016. 
Mais uma vez, encontra-se aqui a ênfase no aprendizado do inglês como uma possibilidade de ganhar dinheiro, vencer na vida, garantindo um diploma que lhe proporcionará, em curto prazo, exercer uma atividade bem remunerada. Nota-se, portanto, que esses termos integram um sistema de restrições que confere validade a esse tipo de discurso, tal que o uso que se faz desses elementos vocabulares só faz sentido se tomado no conjunto desse funcionamento discursivo, por meio do qual se marcam posições e organizam-se unidades temáticas (MAINGUENEAU, 2008).

Esse sentido atribuído ao aprendizado do inglês, enquanto uma possibilidade de alcançar sucesso na vida, conseguir um pretenso bom emprego (bem remunerado), também pode ser verificado em anúncios do final da década de 1980, como se pode observar em:

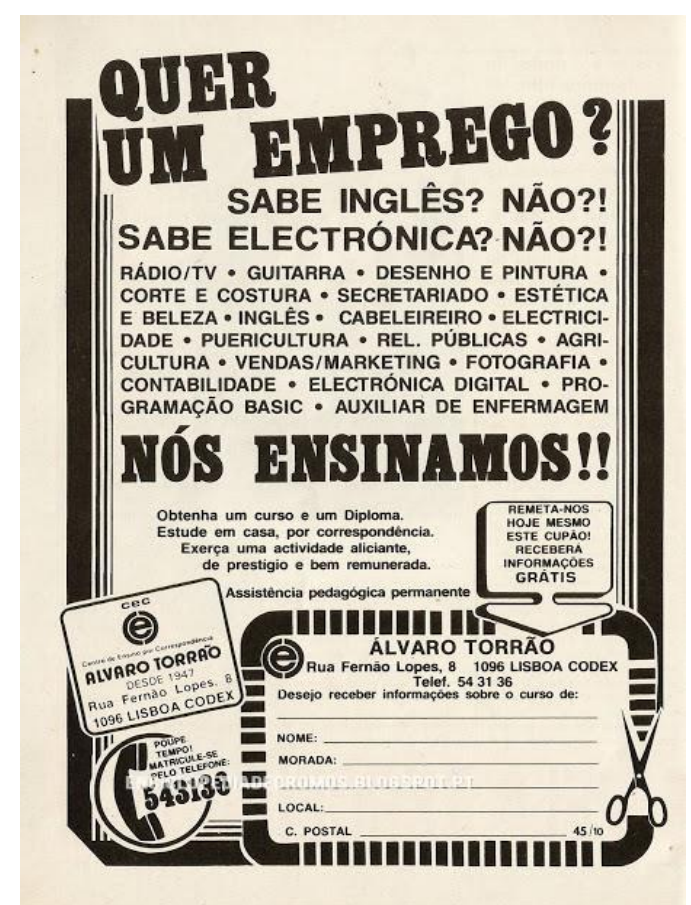

Figura 8. Centro de Ensino por Correspondência Álvaro Torrão.

Fonte: Anúncio retiradoda revista Maria, $n^{\circ} 463$, de setembro de $1987^{8}$.

É interessante destacar mais uma vez que esses enunciados colocam em circulação concepções ideológicas que se fazem presentes, no Brasil, desde a fundação dos primeiros cursos livres de idiomas em solo nacional, os quais cumpriram desde sempre o seu papel de disseminadores da cultura anglófona, cuja influência ideológica é sentida até hoje. Nesse aspecto, cabe trazer à tona a fala de Oliveira (2014) quando afirma que:

foi essa influência que desempenhou um papel fundamental na construção do mito de que todos os brasileiros precisam aprender inglês para serem profissionalmente bem-sucedidos. E é um mito porque, obviamente, muitas profissões não exigem o conhecimento da língua

8 Esse folheto também pode ser encontrado por meio da página: http://3.bp.blogspot.com/7aLQcBF_Af8/Ug9CsyU7zsI/AAAAAAAAStc/REhvRcyINT0/s640/maria463pub_06cecalvarotorrao01. jpg. Acesso em 10 ago. 2016. 
inglesa e porque muitas pessoas que dominam a língua inglesa não conseguem um emprego bem remunerado, quando conseguem um emprego. (OLIVEIRA, 2014, p. 63)

É interessante notar como esse tipo de formação discursiva pode ser recuperada com o passar dos tempos, por meio do acesso à materialidade linguística que atravessa o fio discursivo de enunciados postos em circulação em diferentes momentos de enunciação, delimitando um espaço próprio de regularidades associadas a determinadas condições de produção sócio-históricas (MAINGUENEAU, 2012).

Inegavelmente, diferentes contextos de EAD revelam maneiras particulares de se fazer uso de determinados recursos tecnológicos a fim de dar suporte ao processo de ensino e aprendizagem. Avançando um pouco no tempo, acredita-se que a utilização de materiais impressos, voltados à aprendizagem de LE, em conjunto com as experiências radiofônicas de ensino de inglês ampliaram as possibilidades de desenvolvimento de habilidades linguísticas dos estudantes.

Essas práticas buscaram inserir o elemento da escuta em LE como uma prática para além da mera abordagem centrada na leitura e na escrita, habilidades estas desenvolvidas por meio do estudo de fragmentos textuais e atividades de estrutura gramatical que, provavelmente, eram a base articuladora da abordagem utilizada nos materiais exclusivamente impressos.

Com a televisão as atividades de áudio ganharam um ingrediente a mais, a inclusão do vídeo como um elemento de apoio ao processo de ensino e aprendizagem. Destaca-se, fundamentalmente, o quanto a linguagem vai se entrelaçando a tecnologia a fim de garantir possibilidades de ensino de LE para além do foco centrado em atividades unicamente de leitura e escrita, presentes no material estritamente impresso.

Observa-se, assim, que a televisão implicou na produção de material didático específico para o uso desse suporte em contextos de aprendizagem a distância, tal que por meio das vídeo-aulas o estudante tem a possibilidade de ter contato com práticas de escuta no idioma alvo, além do aspecto visual e da interação com situações reais ou simuladas de uso da língua em ambiente natural de comunicação.

Em sua maioria, esses materiais eram produzidos com foco em conversações que simulavam diálogos entre nativos em diferentes situações de uso da língua. A ênfase em atividades comunicativas com a presença de falantes nativos nos materiais de áudio é também empregada nos materiais seriados impressos que vem acompanhados de um conjunto de recursos didáticos para ser utilizado pelos estudantes, desde o CD de áudio para escuta e práticas de pronúncia nas atividades com imagens e dicas de cultura, até jogos e exercícios digitais disponibilizados em ambiente virtual.

Cita-se, aqui, o curso de idiomas Inglês em 5 minutos diários da Berlitz, que é descrito como um curso novo e prático que alia fotos a atividades de áudio para facilitar o aprendizado da LE, com lições dinâmicas e objetivas, jogos, brincadeiras, além de exercícios disponíveis on-line. O material destaca o papel do uso de CD de áudio com falantes nativos como um incremento relevante dentro da metodologia proposta pelo material. 
Ainda no que diz respeito aos materiais seriados, pode-se destacar outros elementos, como se depreende pela figura seguinte:

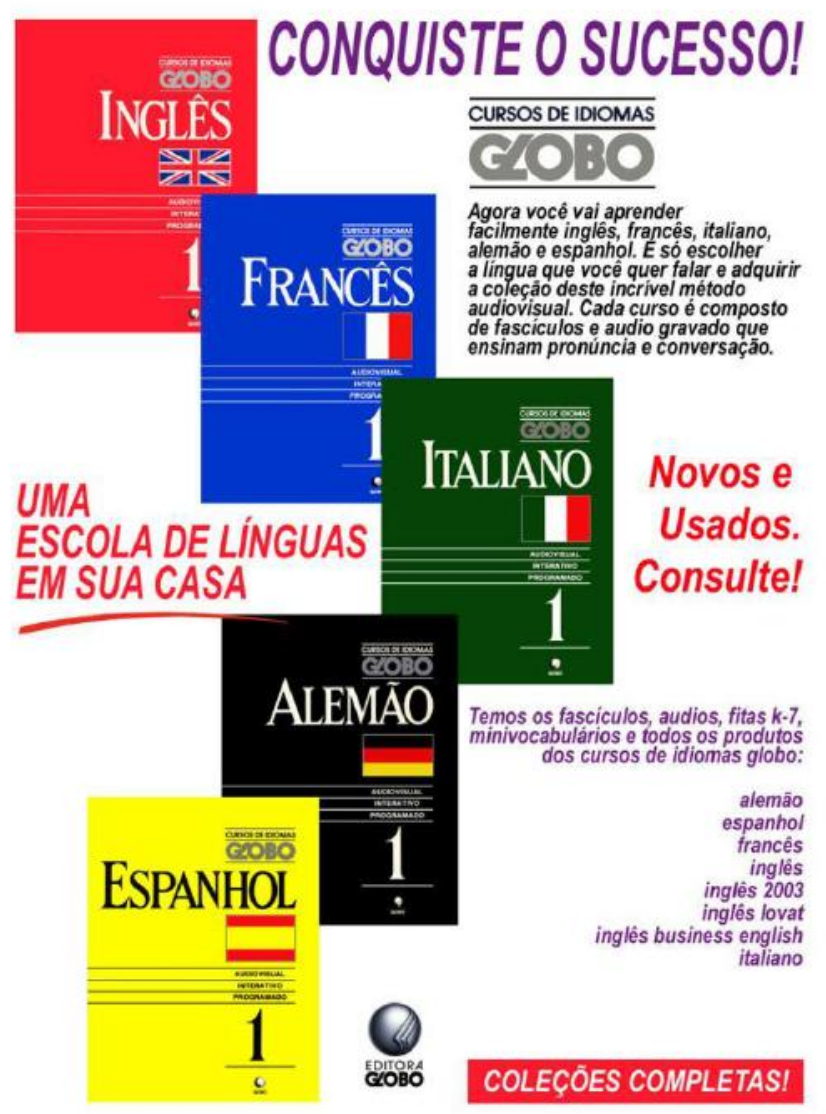

Figura 9. Anúncio on-line do Curso de Idiomas Globo - Coleções completas. Fonte: http://2.bp.blogspot.com/_DMFEabG20es/TQp2GMCNLDI/AAAAAAAAAWI/M6vi9w1t8Lw/s1600/NOVOIDIOMA SGLOBOnov2010.jpg.

Na figura 9, o sentido de obter sucesso na vida, a partir da aprendizagem de inglês, desliza, em certa medida, para a necessidade de se aprender qualquer LE. Ainda que um material dessa natureza possa vir a focar na estrutura da língua, reconhece-se o papel desempenhado pelo material de áudio como um elemento importante no desenvolvimento de outras habilidades linguísticas, podendo o aluno ir além da leitura e escrita, como já mencionado. Por outro lado, essa necessidade de aprendizagem de LE traz a reboque a perspectiva de que um falante com proficiência significativa em outros idiomas tende a ser um indivíduo com possibilidades de atuar em um mundo cada vez mais globalizado, tornando-se, assim, um indivíduo bem-sucedido.

Se em determinada época o inglês, assim como o conhecimento técnico em eletricidade, taquigrafia, corte e costura, entre outros, era concebido como um elemento da formação profissionalizante, para a capacitação de brasileiros para o mercado de trabalho, essa concepção vai ganhando outros contornos ao longo dos anos, não se distanciando muito dessa perspectiva. Entretanto, a inserção do cidadão em um mundo cada vez mais globalizado parece ditar as regras do jogo, em especial com o surgimento 
da Internet, dando cada vez mais ênfase ao aprendizado de inglês como um diferencial, uma forma de se ter acesso ao conhecimento em âmbito mundial.

Para Paiva (1999), um dos principais desafios do estudante no que toca ao desenvolvimento da comunicação em contextos de aprendizagem de LE sempre foi a ausência de contato com falantes nativos e de oportunidades de interação em ambiente real de interação. $\mathrm{O}$ fato dos materiais seriados trazerem o componente da voz do nativo nos CDs de áudio tenderia, então, a, de certa forma, aproximar o estudante de contextos de uso da língua por quem, de fato, fala o idioma como língua materna.

Ainda segundo a estudiosa, a Internet tem auxiliado a romper com essa limitação, permitindo que os estudantes de línguas possam desenvolver as habilidades linguísticas em inglês, interagindo com falantes nativos por meio de chats, potencializando as oportunidades de aprendizagem no ambiente virtual.

Observe:

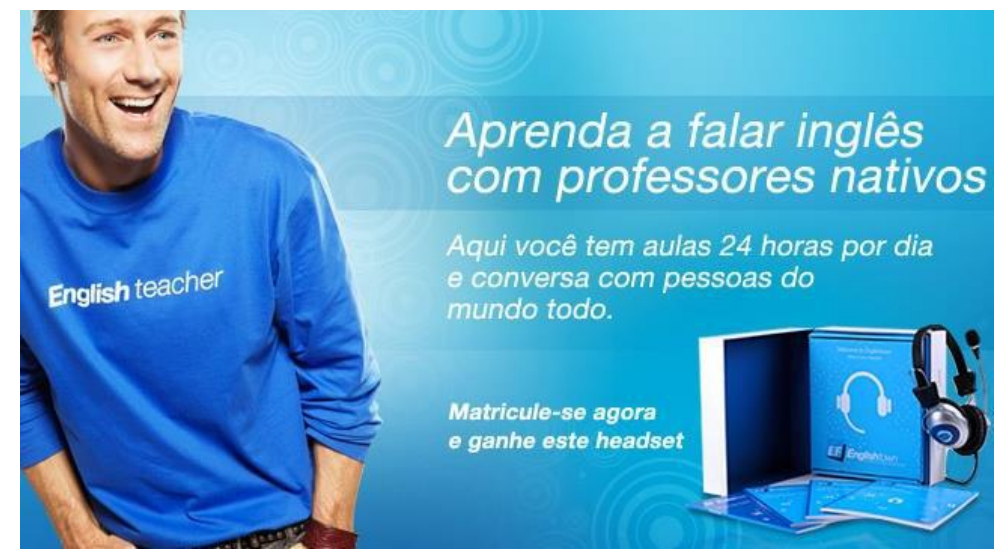

Figura 10. Anúncio do Curso Englishtown. Fonte:

http://www.englishtown.com/_imgs/br_design/email/november/02/images/email_02_02.jpg. Acesso em 06 nov. 2017.

Como se pode observar na figura 10, enunciados que veiculam dizeres sobre a relevância de se ter contato com professores nativos parece ser bastante comum nesse tipo de modalidade, e que se verifica em diferentes anúncios em panfletos de divulgação de cursos on-line na Internet, tentando disseminar a ideologia de que ter um professor de inglês que fala o idioma alvo como língua materna agregaria mais valor do que um professor brasileiro, não nativo de países anglófonos.

Ainda acerca das potencialidades das oportunidades de aprendizagem e interação em ambiente virtual, pode-se dizer que:

essa ampliação de oportunidades de interação amplia não só o universo do aluno, mas também do professor, que não está mais isolado em sua sala de aula. Através da Internet, ele ou ela pode interagir com colegas no mundo inteiro, trocar experiências, pedir auxílio e continuar a se 
formar através da troca de experiências com colegas de profissão. (PAIVA, 1999, p. 56)

Nessa mesma direção, Silveira (2015) ressalta os diversos recursos didáticos à disposição de estudantes de LE em sites da Internet, por meio dos quais "os aprendizes podem encontrar textos, jogos, exercícios com respostas on-line, arquivos com som, imagem e vídeo, texto autênticos da língua alvo e chats com falantes nativos" (SILVEIRA, 2015, p. 29).

Em muitos outros anúncios de cursos de inglês na modalidade EAD oferecidos on-line, percebe-se a ênfase recorrente a pretensa flexibilidade, ou aprendizagem flexível como propõe Paiva (1999), porém, de modo um pouco distorcido. Enquanto a pesquisadora aborda o aspecto inovador da Internet, ao introduzir novas relações metodológicas nos processos educativos com a possibilidade de fomento da interação, a flexibilidade nos anúncios dos panfletos virtuais muitas vezes está atribuída, basicamente, ao simples fato de que o aluno pode estudar no conforto do seu lar - "uma escola de línguas em sua casa" -, a qualquer hora, em qualquer lugar, sem precisar do professor; de forma bastante divertida e interessante, em contraponto ao ensino ofertado em ambiente formal na modalidade presencial, como se pode observar pelos exemplos seguintes:

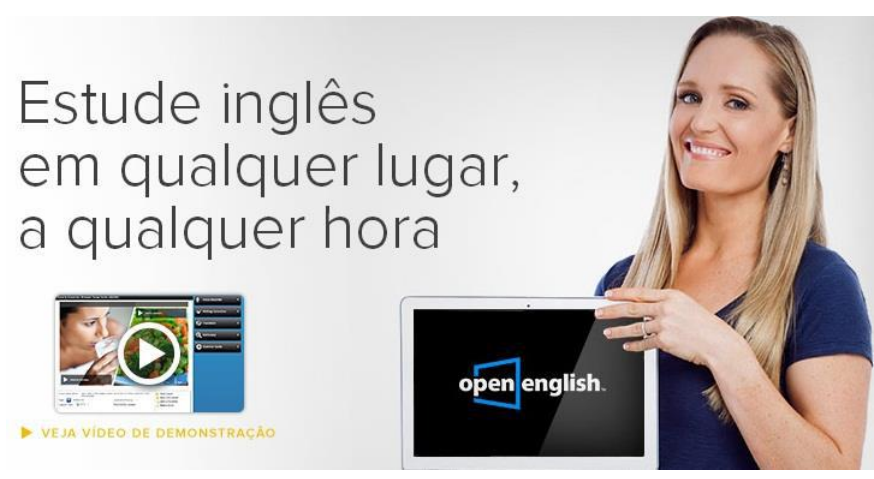

Figura 11. Anúncio do Curso Open English. Fonte: http://www.marketingnasies.com.br/wp-content/uploads/2013/09/Open_English1.jpg. Acesso em 11 jun. 2017.

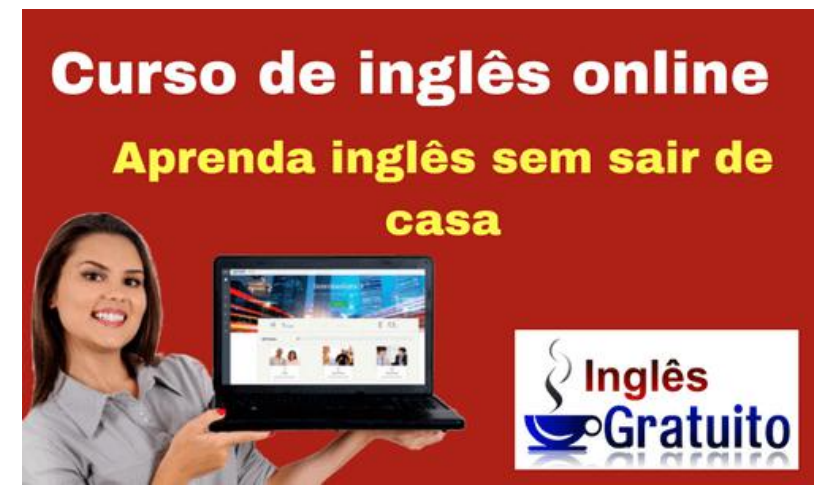

Figura 12. Curso de inglês na modalidade on-line. Fonte: http://www.inglesgratuito.com.br/wp-content/uploads/2017/01/Curso-de-ingl\%C3\%AAs-on-line-10.png. Acesso em 11 jun. 2017. 
Para além do discurso da aprendizagem de inglês em ambiente extraclasse, no conforto do seu lar, aspectos como aprender sozinho e o discurso de que se pode estudar inglês sem precisar pagar por isso atuam como fatores atrativos nos enunciados proferidos por esses anúncios veiculados em mídia virtual.

Além disso, destaca-se também, assim como nos enunciados em circulação com os cursos por correspondência entre as décadas de 1940 e 1980, a recorrência da ênfase dada ao discurso de que bons cursos seriam aqueles em que os alunos aprendem inglês em pouco tempo, como observado nas figuras 13 e 14 :

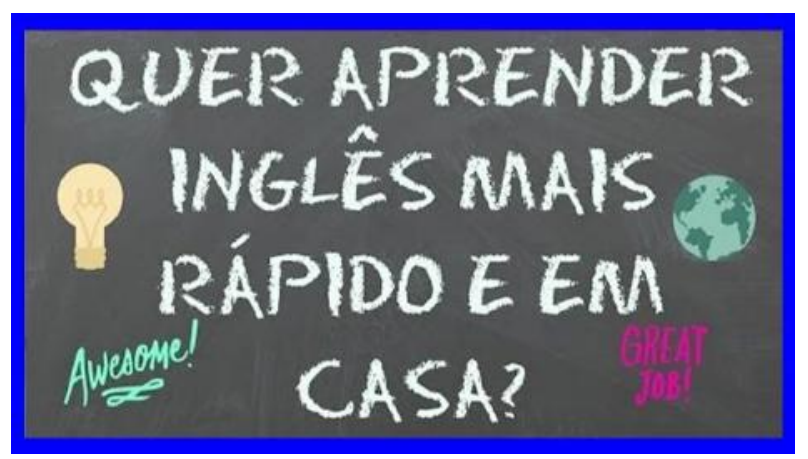

Figura 13. Inglês rápido e em casa. Fonte: https://i.ytimg.com/vi/uvMRu-XuLas/maxresdefault.jpg. Acesso em 11 jun. 2017.

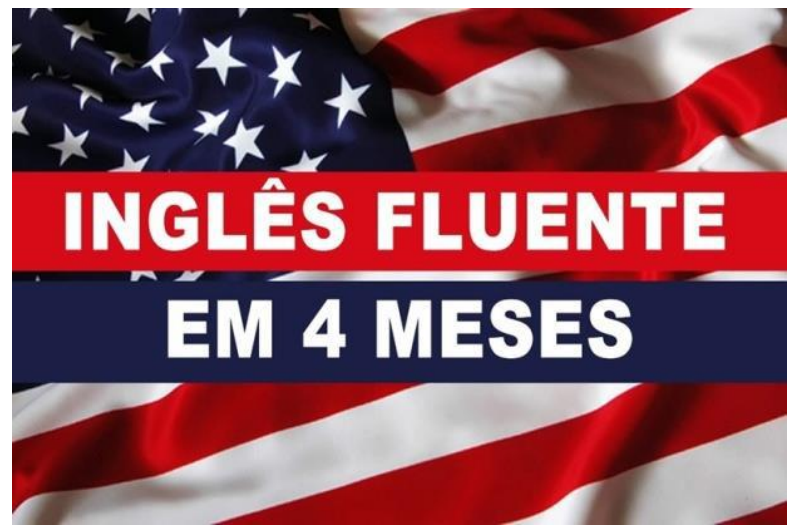

Figura 14. Inglês fluente. Fonte:

http://learnesaude.com/wp-content/uploads/sites/1723/2015/08/Aprenda-Ingl\%C3\%AAs-Rapido.jpg. Acesso em 11 jun. 2017.

Partindo desses diferentes textos, em circulação por meio de diferentes suportes e em diferentes épocas, pode-se dizer que há uma regularidade no funcionamento discursivo dos recortes em análise que nos permite pensar os sentidos de vencer na vida, ganhar dinheiro, obter sucesso como elementos semânticos que circunscrevem o tema da prosperidade, relacionados que estão à aprendizagem de inglês.

Por meio dessa concepção ideológica, que mobiliza esse processo de significação, é que se entende que se torna imprescindível buscar maneiras de se alcançar sucesso de modo prático, dinâmico, rápido, com o menor esforço possível. Isso tende a se 
materializar em práticas que envolvem o estudo desse idioma sem sair de casa, em atividades desenvolvidas a qualquer hora, e em qualquer lugar.

Vejamos a figura seguinte:

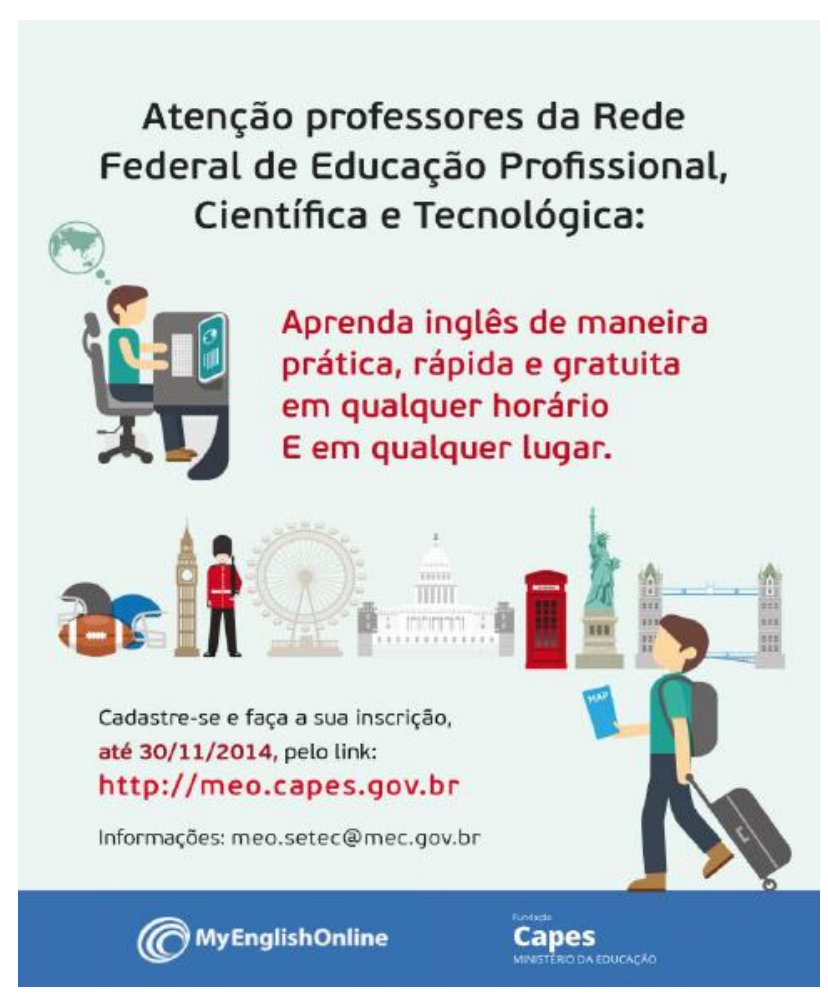

Figura 15. My English On-line (MEO). Fonte: http://prodin.ifpa.edu.br/images/my_english.png. Acesso em 05 jan. 2017.

Considerar os enunciados postos em circulação por meio da figura 15 , no seio desse processo de significação que aqui está em jogo, só faz sentido se tomarmos esses dizeres em relação interdiscursiva com outros enunciados que se filiam a formações discursivas em destaque neste trabalho.

Por meio desses mecanismos de funcionamento, levando em conta a historicidade desses textos, afirma-se que esses sentidos estão sustentados por um já-dito, sentidos institucionalizados, naturalizados, estabelecendo, assim, uma relação ideológica com outros dizeres, inscritos em outras formações discursivas que falam de outro lugar, mas que podem ser recuperados pelo interdiscurso.

\section{Considerações finais}

Buscou-se, aqui, à luz de um viés discursivo, sob a lente da semântica global, apresentar um olhar sobre o percurso histórico do ensino e da aprendizagem de inglês a distância no Brasil, com o intuito de dar a ver os sentidos postos em circulação sobre 
aprender inglês em diferentes contextos de EAD, levando em conta, de forma bastante resumida, suas condições de produção.

Em um primeiro momento, destacamos as experiências com o ensino por correspondência, em que os materiais impressos atuavam como suporte ao processo de aprendizagem de inglês, por meio de atividades que acreditamos ter o foco exclusivamente na língua enquanto estrutura, limitando as possibilidades de desenvolvimento das habilidades linguísticas dos estudantes. Essas iniciativas desempenharam papel importante na promoção de práticas de formação profissionalizante, pactuadas com a capacitação de brasileiros para o mercado de trabalho.

Com as experiências radiofônicas, tem-se a possibilidade de ir além de práticas de leitura e escrita em inglês, agregando aos materias impressos o aspecto da escuta em LE, possibilitando, assim, o contato do estudante com a língua em sua modalidade oral. A televisão impulsionou a produção de material específico para o uso desse tipo de tecnologia, ampliando substancialmente as possibilidades de aprendizagem pelo contato do estudante com o elemento áudio-visual, aliado às dinâmicas de conversação em situações simuladas de interação em ambiente natural de comunicação, como no caso das vídeo-aulas de inglês do Telecurso, por exemplo.

Com os materiais seriados é possível dizer que se potencializa o uso variado de recursos didáticos, materializado sob a forma de livros, com CDs, DVDs, atividades diversificadas, incluindo, inclusive, acesso à Internet. Esses materiais tendem a possibilitar que a abordagem passe a conceber a língua como comunicação, em lugar da língua como mera estrutura (gramatical). Aprender inglês, então, estaria vinculado ao desenvolvimento de habilidades linguísticas com enfoque na competência comunicativa do falante, o que será possível, segundo a concepção ideológica subjacente, se o estudante tiver contato com falantes nativos, como professores ou outros pares de comunicação.

Nesse caso, as oportunidades oferecidas pela Internet tornam-se relevantes nesse processo, pois por meio dela os usuários têm acesso a diferentes recursos, materiais variados, que permitem o desenvolvimento das quatro habilidades linguísticas, a saber: a fala, audição, a escrita e a leitura (SILVEIRA, 2015).

Além disso, ao analisar os folhetos impressos e panfletos de divulgação, recuperados por meio da Internet, os resultados mostram que o tema da prosperidade atravessa as formações discursivas de enunciados que são disseminados acerca do aprender inglês nesses diferentes contextos, inscrevendo a língua nos diferentes materiais didáticos ora como estrutura ora como comunicação, mobilizando, por conseguinte, elementos semânticos atribuídos à aquisição de sucesso por meio do estudo desse idioma.

Faz-se necessário frisar, por fim, que esses enunciados colocam em circulação concepções ideológicas que se fazem presentes, no Brasil, desde a fundação dos primeiros cursos livres de idiomas em solo nacional, os quais cumpriram desde sempre o seu papel de disseminadores da cultura anglófona, cuja influência ideológica é sentida até hoje.

Espera-se, portanto, que este texto possa vir a iluminar futuros estudos acerca dos sentidos veiculados sobre ensinar e aprender inglês em diferentes contextos de EAD, sem 
desconsiderar as condições específicas de produção, cooperando sobremaneira com oportunidades outras de estabelecer uma interlocução profícua entre tecnologia e linguagem, refletindo sobre o papel dos recursos tecnológicos, com suas finalidade pedagógicas, junto ao processo de ensino e aprendizagem de LE.

\section{Referências}

ALVES, J.R.M. A história da educação a distância no Brasil. Carta Mensal Educacional. Publicação do Instituto de Pesquisas Avançadas em Educação, ano 16, n. 82, jun. 2007. Disponível em http://www.ipae.com.br/pub/pt/cme/cme_82/index.htm. Acesso em 11 jun. 2017.

ARAÚJO, J.; LEFFA, V. (Orgs.). Redes sociais e ensino de línguas: o que temos de aprender? São Paulo: Parábola Editorial, 2016.

DANTAS, L.H. Estilos de aprendizagem no ensino da língua inglesa na modalidade de educação a distância. Educação a Distância, Batatais, v. 2, n. 1, 107-122, junho 2012.

FINARDI, K.; PORCINO, M.C. Facebook na ensinagem de inglês como língua adicional. Em: ARAÚJO, J.; LEFFA, V. (Orgs.). Redes sociais e ensino de línguas: o que temos de aprender? São Paulo: Parábola Editorial, 2016. p. 93-109.

FIORIN, J.L. Linguagem e ideologia. São Paulo: Ática, 1998.

GOMES, S.G.S. Histórico da EAD no Brasil. e-TEC Brasil - Tópicos em educação a distância, 2011, 35-47. Disponível em http://ftp.comprasnet.se.gov.br/sead/licitacoes/Pregoes2011/PE091/Anexos/Eventos_mo dulo_I/topico_ead/Aula_03.pdf. Acesso em 10 jun. 2017.

GUARANYS, L.R.; CASTRO, C.M. O ensino por correspondência: uma estratégia de desenvolvimento educacional no Brasil. Brasília: IPEA/IPLAN, 1979.

HACK, J.R. Introdução à educação a distância. Florianópolis: LLV/CCE/UFSC, 2011.

HOLMBERG, B. The evolution of the character and practice of distance education. Open Learning, 47-53, jun. 1995. Disponível em http://www.c31.unioldenburg.de/cde/found/holmbg95.htm. Acesso em 10 jun. 2017.

KAMPFF, A.J.C. Tecnologia da informação e comunicação na educação. Curitiba, PR: IESDE Brasil, 2009.

KENSKI, V.M. Educação e tecnologias: o novo ritmo da informação. Campinas: Papirus, 2007.

MAINGUENEAU, D. Gênese dos discursos. Trad. Bras. São Paulo: Parábola, 2008. 
Novas tendências em análise do discurso. Trad. Bras. $3^{\text {a }}$. ed. Campinas: Pontes; Ed. da Unicamp, 1997.

MEO. My English On-line - CAPES/MEC. Sobre o My English On-line. 2013. Disponível em http://www.myenglishon-line.com.br/saiba-mais. Acesso em 31 mai. 2017.

MORAN, J.M. Ensino e aprendizagem inovadores com tecnologias audiovisuais e telemáticas. Em: MORAN, J.M.; MASETTO, M.T.; BEHRENS, M.A. Novas tecnologias e mediação pedagógica. Campinas: Papirus, 2000. p. 11-65.

MUGNOL, M. A educação a distância no Brasil: conceitos e fundamentos. Rev. Diálogo Educ., Curitiba, v. 9, n. 27, 335-349, maio/ago. 2009.

OLIVERIA, L.A. Métodos de ensino de inglês: teorias, práticas, ideologias. São Paulo: Parábola, 2014.

PAIVA, V.L.M.O. O papel da educação a distância na política de ensino de línguas. Em: MENDES, E.A.M.; OLIVEIRA, P.M.; BENN-IBLER, V. (Orgs.). Revisitações: edição comemorativa: 30 anos da Faculdade de Letras/UFMG. Belo Horizonte: UFMG/FALE, 1999. p. 41-57.

PETERS, O. A educação a distância em transição: tendências e desafios. Trad. Bras. São Leopoldo, RS: Editora Unisinos, 2012.

PIVA JR, D. et al. EAD na prática: planejamento, métodos e ambientes de educação online. Rio de Janeiro: Elsevier, 2011.

SILVEIRA, D.G.S. O ensino de língua inglesa à distância: caminhos e possibilidades. Revista Multitexto, v. 3. n. 2, 28-32, 2015.

SOUZA, C.F. Ecos do ser e do estar: um estudo discursivo acerca do trabalho do professor de inglês de cursos livres. Dissertação. Mestrado em Estudos de Linguagem, Instituto de Letras, Universidade Federal Fluminense, Niterói, 2016.

TELECURSO 2000. A metodologia telessala. Por uma educação básica progressista, libertária e multicultural. s/ano. Disponível em http://educacao.globo.com/telecurso/noticia/2014/11/metodologia-telessala.html. Acesso em 11 jun. 2017.

THOMPSON, D. A compendious history of distance education. Saylor. 2016. Disponível em https://www.saylor.org/2016/09/blog-a-compendious-history-ofdistance-education/. Acesso em 10 jun. 2017.

TORI, R. Educação sem distância: as tecnologias interativas na redução de distâncias em ensino e aprendizagem. São Paulo: Editora Senac São Paulo, 2010. 
Artigo recebido em: julho de 2017.

Aprovado e revisado em: outubro de 2017.

Publicado em: novembro de 2017.

\section{Para citar este texto:}

SOUZA, Carlos Fabiano de. Do ensino por correspondência ao My English Online: retratos do ensino de inglês a distância no Brasil. Entremeios [Revista de Estudos do Discurso, on-line, www.entremeios.inf.br], Seção Temática [Linguagem e Tecnologia], Programa de Pós-Graduação em Ciências da Linguagem (PPGCL), Universidade do Vale do Sapucaí (UNIVÁS), Pouso Alegre (MG), vol. 15, p. 369-397, jul. - dez. 2017.

DOI: http://dx.doi.org/10.20337/ISSN2179-3514revistaENTREMEIOSvol15pagina369a397 